Безтелесна Л. I. [1; ORCID ID: 0000-0002-0262-9334], д.е.Н., професор, Василів В. Б. [1; ORCID ID: 0000-0003-4152-3345], к.Т.н., доцент

${ }^{1}$ Національний університет водного господарства та природокористування, м. Рівне

\title{
ОРГАНІЗАЦІЙНО-ПЕДАГОГІЧНИЙ МЕХАНІЗМ ФОРМУВАННЯ ЦИФРОВОЇ КОМПЕТЕНТНОСТІ СТУДЕНТІВ УНІВЕРСИТЕТІВ
}

Система освіти України створює для особи широкі можливості, серед них і здобуття загальних і професійних компетентностей. Однією 3 ключових є цифрова компетентність. Зважаючи на швидку зміну технологій, світова економіка зіштовхується 3 дефіцитом людей 3 цифровими навичками. Саме тому більшість країн включають навчання цифровим навичкам як частину загальної стратегії освіти та розвитку національної цифрової економіки. Міністерством цифрової трансформації України створено портал «Дія», на якому за допомогою тесту «Цифрограм» громадянам надано можливість перевірити цифрову грамотність. Середня оцінка цифрової грамотності студентів контрастує 3 статистикою використання інформаційно-комунікаційних технологій молоддю. Дослідження показали, що значні обсяги використання комп'ютерів, мобільних пристроїв та Інтернету сприяють лише цифровим навичкам на операційному рівні. Значне за обсягом/часом споживання цифрових технологій не можна розглядати як доказ цифрової компетентності. Молодь є в основному споживачем чужого контенту, а не творцем нового, самостійно створеного. Запропоновано запровадити тестування цифрових навичок студентів першого курсу i залежно від їхнього рівня диференціювати навчальні програми та формувати індивідуальні навчальні траєкторії. Необхідна зміна парадигми здобуття цифрових навичок: перехід від традиційного надання контенту і відомостей до супроводу студентів у створенні цифрового контенту, розробці практико-орієнтованих проектів. Для досягнення успіху необхідна ефективна між секторальна взаємодія стейкхолдерів державних органів, університетів, IT-компаній, громадських організацій. Сприятиме успіху також запровадження адресної політики з покращення цифрових компетенцій щодо певних груп населення.

Ключові слова: цифрові компетенції; тестування; освітня траєкторія; сертифікат.

у нинішніх умовах університети зі змішаною системою фінансування функціонують як некомерційні підприємницькі структури, а відтак змушені провадити діяльність у конкурентному 
середовищі. Саме тому вони повинні використовувати уже наявні та впроваджувати нові механізми забезпечення конкурентоспроможної діяльності.

Освіта України створює для особи широкі можливості, серед них і здобуття загальних і професійних компетентностей [1]. У системі вищої освіти компетентності здобуваються ще на вищому рівні, а ніж у середній, у відповідній галузі знань за певною кваліфікацією [2]. Функціонування вищої освіти у суспільстві переслідує мету формування людських ресурсів на основі компетентнісного підходу для національної економіки.

Людські ресурси $\epsilon$ цінним ресурсом, вартість якого може зростати або втрачатися [3]. Переважно важливість компетентності людських ресурсів розглядають з позиції діяльності їх в організаціях. Саме так стверджує В. Макелвіл, що серцевиною організації $\epsilon$ набір компетенцій всіх працівників, які ними володіють [4]. Г. Каннака доводить необхідність розвивати компетенції у кожного працівника організації заради досягнення успіху всієї діяльності і визначає компетенцію фірми, як раціональне поєднання знань та здібностей, що розглядаються у невеликому проміжку часу, якими володіють працівники даної організації [5]. Boyatzis пропонує під компетенцією людських ресурсів розуміти сукупність факторів знань, навичок і способів спілкування [6].

У сучасних умовах інформаційної економіки людські ресурси повинні формувати і володіти цифровою компетентністю. Європейський парламент і Рада Європейського Союзу 17 січня 2018 року схвалили Рамкову програму оновлених ключових компетентностей для навчання протягом життя. Однією з восьми запропонованих є цифрова компетенція (Digital competence) [7].

Рівень цифрової компетентності найближчими десятиліттями визначатиме конкурентоспроможність персоналу при прийнятті на роботу, а якісне володіння цифровими навичками стане однією 3 обов'язкових вимог роботодавців. Цифрові навички людського капіталу мають бути сформовані на трьох рівнях: 1) вищий рівень навички управління цифровою економікою та цифрового підприємництва: вміння визначати нові можливості для бізнесу, нові бізнес-моделі, нові способи ведення бізнесу, вміння впроваджувати інновації та управляти змінами; 2) середній рівень - цифрові спеціалізовані навички: навички, необхідні для дослідження, розробки, проєктування, стратегічного планування, управління, виробництва, консалтингу, маркетингу, продажу, інтеграції, встановлення, адміністрування, підтримки та обслуговування програмного забезпечення та систем IKT; 3) низовий рівень - 
навички цифрових користувачів: цифрова грамотність, навички, необхідні для ефективного використання засобів, систем та пристроїв IKT, що охоплюють використання інтернету, додатків, основного та вдосконаленого програмного забезпечення та спеціалізованих інструментів, що підтримують конкретні бізнесфункції [8].

Нерівність в цифрових навичках посилює нерівність між країнами, що розвиваються і розвиненими країнами, та окремими соціальними групами [9]. Значимість цифрових навичок для громадян очевидна в рамках виявлення переваг і відчутних результатів, отриманих в ході освоєння і застосування ІКТ. Саме навички виступають ключовим фактором, що визначає, чи можуть люди перетворити використання вебресурсів в реальні вигоди (наприклад, переваги при влаштуванні на роботу, навчання в системі дистанційної освіти, користування державними і муніципальними послугами в електронному форматі).

Всесвітній економічний форум оприлюднює Networked Readiness Index (NRI) - індекс мережевої готовності, який на тепер вважається одним з найбільш важливих показників інноваційного та технологічного потенціалу країн світу і можливостей їх розвитку в сфері високих технологій і цифрової економіки. Він використовується як засіб аналізу та для побудови порівняльних рейтингів, що відображають рівень розвитку інформаційного суспільства в різних державах. Існує тісний зв'язок між розвитком ІКТ та економічним благополуччям, оскільки ІКТ відіграють сьогодні провідну роль у розвитку інновацій, підвищення продуктивності та конкурентоспроможності, диверсифікують економіку і стимулюють ділову активність, тим самим сприяючи підвищенню рівня життя людей [10].

Україна займає в 2020 р. 64 місце з 134 країн, які увійшли до рейтингу. Варто зазначити, що незважаючи на всі програми і намагання уряду, позиція України у цьому рейтингу з 2016 року не змінилась.

Тобто в Україні спостерігається розвиток інформаційнокомунікаційних технологій і мережевої економіки, однак прогрес відносно інших країн незначний.

Реагуючи на незначні темпи прогресу у ІКТ України щодо інших країн, Урядом розроблено у 2020 р. Концепцію розвитку цифрових компетентностей. Згідно до неї цифрова компетентність - впевнене, критичне та творче користування засобами інформаційнокомунікаційних технологій (ІКТ) для роботи, працевлаштування, 
навчання, дозвілля, включення та/або участі у суспільстві [11].

Реалізуючи положення Концепції, Міністерством цифрової трансформації України в межах проекту «Цифрова держава» створений портал «Дія», який має на меті об'єднати всі відомства в єдину зручну й дієву онлайн-систему [12].

Міністерство цифрової трансформації оприлюднило результати власного дослідження щодо володіння населенням України цифровими навичками, а саме: інформаційними, комунікаційними, пошуком вирішення проблеми і ПЗ користувалися інтернетом останні три місяці. Це дослідження було першим в Україні та в його основу було покладено методологію, що використовується Європейською комісією для обрахунку Індексу цифрової економіки та суспільства. Цей індекс складається з таких показників: підключення до мережі Інтернет, людський капітал, використання Інтернет, інтеграція цифрових технологій, цифрові державні послуги. Згідно 3 результатами загальнонаціонального опитування 3 цифрової грамотності, яке проводилось Міністерством цифрової трансформації у 2019 році, засвідчили, що досить висока частка українців не володіють базовими цифровими навичками, а саме $37,9 \%$ українців у віці 18-70 років мають цифрові навички на рівні нижче середнього, ще 15,1\% взагалі не володіють ними. Таким чином, 53\% населення України за методологією оцінки цифрових навичок, яка застосовується Європейською комісією, знаходяться нижче позначки «середній рівень» [13]. Разом 3 тим, було виявлено рівень зацікавленості навчанням населення у розрізі вікових груп. Найвищою зацікавленість у здобутті цифрових компетенцій належить молоді, у групі 10-17 років $(67,5 \%)$ та $18-29$ років $(61,4 \%)$. Навчання цифровим навичкам актуальне лише $47 \%$ українців у віці 18-70 років. Переважно, це молодь. Пояснюється це просто, зацікавленість у навчанні прямо пропорційна рівню володіння цифровими навичками населення. Чим нижче рівень цифрових компетенцій, тим гірше актуалізований запит на опанування новими навичками. А відтак переважно декларується неактуальність навчання. I навпаки, вищий рівень цифрових навичок актуалізує потребу в поглибленні наявних знань та розширенні своїх компетенцій [13].

Цифрові компетенції на сьогодні - це база кожної людини; must-have знання, без яких соціалізуватись, використовувати блага держави, навчатись чи просуватись кар'єрною сходинкою з кожним роком стає дедалі важче. У світі вже існує мільйонів робочих місць, які потребують передових цифрових навичок - big data, кібербезпека, програмування, ІоТ; а робочих місць, що потребують 
знання базових цифрових навиків - в рази більше.

Дедалі частіше експерти стверджують, що в недалекому майбутньому практично кожна робота буде певним чином пов'язана 3 цифровими навичками. Уже в період 2020-2025 років ми зіштовхнемось із серйозним дефіцитом як самих цифрових навичок, так і людей з цифровими навичками, через швидкі зміни технологій. Саме тому все більше країн і міжнародних організацій включають навчання цифровим навичкам як частину загальної стратегії освіти та розвитку національної цифрової економіки. Україна не стоїть осторонь цих процесів. Саме тому у застосунку «Цифрограм» на порталі Дія надана можливість перевірити цифрову грамотність будь-якому громадянину шляхом виконання тесту, завдання якого систематизовані за сферами знань європейської рамки цифрових компетентностей для громадян DigComp 2.1. Враховуючи виклики сьогодення, цю Рамку було адаптовано до національних, культурних, освітніх та економічних особливостей України. Наразі українська версія рамки включає 4 виміри, 6 сфер, 30 компетентностей та 6 рівнів володіння цифровими компетентностями: 1) основи комп'ютерної грамотності; 2) інформаційна та медіаграмотність. Вміння працювати 3 даними; 3) створення цифрового контенту; 4) комунікація і взаємодія у цифровому суспільстві; 5) безпека у цифровому середовищі: 6) вирішення технічних проблем. Навчання впродовж життя у цифровому суспільстві [11].

Звичайно, що пройдене тестування на цифрограмі дає можливість людині отримати сертифікат, який створює масу переваг (табл. 1).

Таблиця 1

Переваги отримання сертифіката про цифрову грамотність

\begin{tabular}{|l|l|}
\hline $\begin{array}{l}\text { Переваги для } \\
\text { роботодавця }\end{array}$ & $\begin{array}{l}\text { швидший і дешевший набір нових працівників; } \\
\text { підвищення продуктивності та якості продукції; } \\
\text { зниження витрат; } \\
\text { збільшення прибутковості витрат на комп'ютеризацію; } \\
\text { підвищення ефективності використання IT-ресурсів. }\end{array}$ \\
\hline $\begin{array}{l}\text { Переваги для } \\
\text { суспільства }\end{array}$ & $\begin{array}{l}\text { підвищення загального рівня IT-компетенції; } \\
\text { підтримка моделі навчання впродовж життя; } \\
\text { відкриття дверей до інформаційного суспільства; } \\
\text { сприятливий вплив на модернізацію економіки країни. }\end{array}$ \\
\hline $\begin{array}{l}\text { Переваги для } \\
\text { власника } \\
\text { сертифікату }\end{array}$ & $\begin{array}{l}\text { підтвердження компетентності; } \\
\text { покращення позиції на ринку праці; } \\
\end{array}$ \\
& $\begin{array}{l}\text { більша впевненість у збереженні зайнятості; } \\
\text { збільшення мобільності; }\end{array}$ \\
\hline
\end{tabular}


Сертифікат «Цифрограм» розроблений 3 орієнтацією на роботодавців. Якщо у вимогах до претендентів на заміщення вакантних посад $€$ вимога про наявність сертифіката цифрової грамотності то роботодавцю або фахівцю із залучення персоналу не доводиться витрачати час на перевірку комп'ютерних навичок кандидатів на роботу, оскільки вони можуть довіряти сертифікату.

Приймаючи нового працівника із сертифікатом, роботодавець впевнений, що ця особа не буде витрачати час на вивчення основних функцій програмного забезпечення чи виконання вручну трудомістких операцій, які можна виконати за допомогою декількох дій на комп'ютері. Також роботодавець може створювати умови для навчання працівників і перевіряти якість їхнього навчання, якщо вони одержують сертифікат. Керівники ІТ-відділу у компаніях стверджують, якщо користувачі ІТ-систем володіють комп'ютерними навичками, підтвердженими сертифікатом, то служба підтримки користувачів має набагато менше роботи. Вигоди, отримані працівниками та роботодавцями, безпосередньо перетворюються на вигоди для суспільства.

Результати дослідження Міністерства цифрової трансформації свідчать, що найбільшу активність до формування цифрових компетенцій має молодь. Для підтвердження цієї тези у процесі дослідження цифрової компетенції молоді, автори узагальнили результати тестування 169 студентів першого курсу Національного університету водного господарства та природокористування. В цілому студенти показали середній рівень цифрової грамотності, 92\% опитаних мають оцінки В1 та В2. Лише 8\% студентів мають високий рівень - С1 (рис. 1).

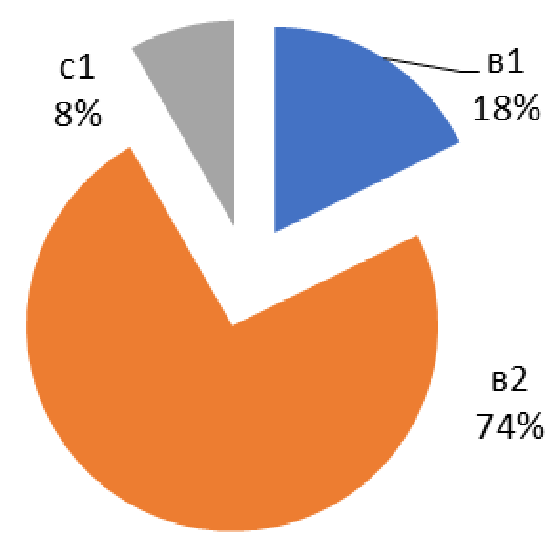

Рис. 1. Рівні володіння цифровими компетенціями студентів університету

Середня оцінка цифрової грамотності студентів контрастує 3 статистикою використання інформаційно-комп'ютерних технологій 
молоддю. В українському суспільстві у віковому розрізі найактивнішими в інтернеті є українці віком від 15 до 24 років серед них частка користувачів інтернетом становить 97\%, люди від 25 до 34 років - 96\%, користувачів віком від 65 років - уже 29\% (рік тому було лише 14\%). Частка жінок у загальній кількості інтернет користувачів становить 52\% [12].

Відповідно випереджаюче використання комп'ютерів, мобільних телефонів та інтернету молоддю в порівняні 3 іншими категоріями населення, не обов'язково означає, що вони розвивають навички та можуть отримати від них користь у багатьох різних аспектах життя. Дослідження показали, що великі обсяги використання комп'ютерів, мобільних пристроїв та інтернету сприяють лише цифровим навичкам на операційному рівні. Вища пізнавальна здатність до критичного пошуку та відбору інформації не $€$ наслідком більшого споживання. Користувачі можуть просто залишатися на одному рівні і використовувати лише деякі конкретні програми та соціальні мережі. Отже, значне за обсягом/часом споживання цифрових технологій не можна розглядати як доказ цифрової компетентності.

Аналіз результатів тестування за групами компетентностей показав що найкращі результати студенти показали 3 основ комп'ютерної грамотності $(0,79)$, а найгірші - створення цифрового контенту $(0,55)$ (рис. 2).

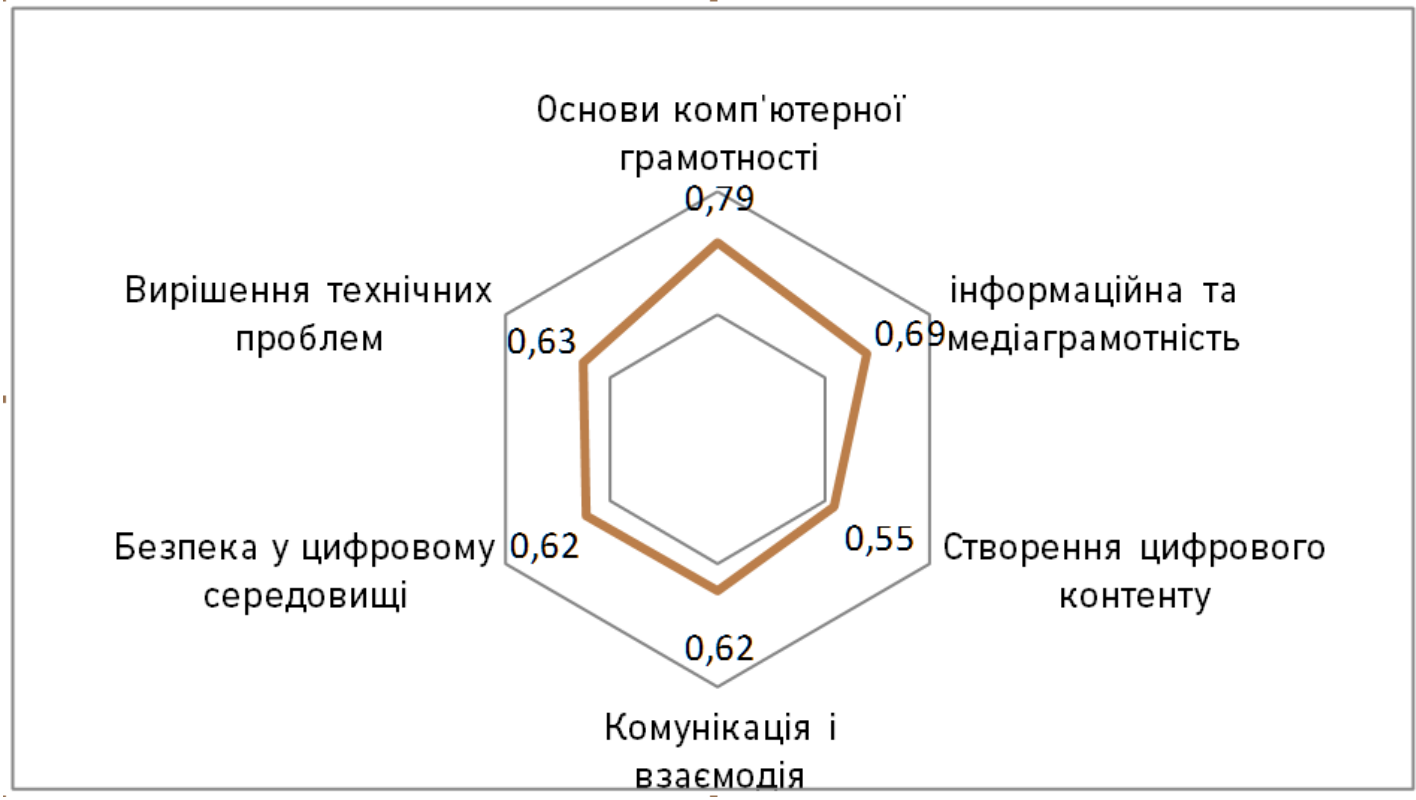

Рис. 2. Рівні володіння цифровими компетентностями студентами за сферами 
Отримані результати дають право стверджувати, що рівень цифрової компетентності молоді (студентів) характеризує їх як споживачів чужого контенту, а не творців нового, самостійно створеного, оскільки рівень знань саме сфери компетентностей «Створення цифрового контенту» $є$ найнижчим.

Сфера компетентностей «Створення цифрового контенту» описується наступними дескрипторами:

С2.К1. Розробка цифрового контенту. Створювати та редагувати цифровий контент у різних форматах, самовиражатися цифровими засобами, бути творцем і продюсером медіаповідомлень. Розуміти переваги і обмеження кожного виду мультимедіа, вміти створювати медіаресурси.

С2.K2. Редагування та інтеграція цифрового контенту. Змінювати, уточнювати, вдосконалювати та інтегрувати інформацію та контент у існуючий масив знань для створення нових, оригінальних і відповідних знань та контенту.

С2.К3. Авторське право і ліцензії. Розуміти, як авторське право і ліцензії поширюються на дані, інформацію та цифровий контент.

C2.K4. Первинні навички програмування. Розуміти, як за допомогою програмування можна вирішити певну проблему чи конкретне завдання. Вміти писати прості програми для цифрових пристроїв.

С2.K5. Творче використання цифрових технологій. Використовувати цифрові засоби та технології для створення знань, ресурсів, продуктів і внесення інноваційних змін у існуючі процеси та продукцію.

Аналізуючи ці дескриптори, очевидно що на низький результат вплинула і недостатня обізнаність молодих громадян про права та етичні норми поводження в цифровому просторі (плагіат, недотримання авторських прав, використання неліцензійного програмного забезпечення тощо).

Власне, ці результати тестування студентів дають можливість до розробки певних рекомендацій для системи вищої освіти, яка зобов'язана формувати цифрові компетенції у молоді.

По-перше, цифровізація економіки і суспільства, постійний розвиток ІТ-технологій вимагає трансформації освітньої інфраструктури, в напрямку безперервного навчання цифрової грамотності.

По-друге, вхідний потік студентів $\epsilon$ неоднорідним. Тому первинне тестування студентів при вступі до університету дає можливість їх розподіляти на групи за різними рівнями володіння 
цифровими компетенціями і диференціювати навчальні програми, але які мають досягати однакових програмних результатів навчання.

По-третє, для кожного студента в університеті, за результатами вхідного та проміжного тестування необхідно сформувати індивідуальну траєкторію здобуття цифрової компетентності. Створення індивідуальної освітньої траєкторії перетворює студента на партнера викладача у процесі власного розвитку. Дослідники зазначають, що студент, котрий бере активну участь у розробці освітньої траєкторії, зростає насамперед у власних очах. Це допомагає підвищенню самоповаги, активізує інтерес молоді до нових знань, сприяє інтелектуальному розвитку та самостійності. Результати руху освітньою траєкторією можна перевіряти, орієнтуючись на створений студентами IT-продукт; отримані знання, які реалізуються в уміннях оперувати ними в стандартній або творчій ситуації.

По-четверте, зміна парадигми навчання в університеті: викладач стає консультантом для студента, бо професійно радить, які компетенції і на яких платформах студент може здобути, як використовувати отримані навички та знання у процесі вирішення життєвих проблем (табл. 2).

Таблиця 2

Зміна парадигми здобуття цифрових навичок

\begin{tabular}{|c|c|c|}
\hline & Традиційний підхід & $\begin{array}{c}\text { Навчання на основі } \\
\text { компетентнісного підходу }\end{array}$ \\
\hline Викладач & $\begin{array}{c}\text { Надання контенту та } \\
\text { відомостей }\end{array}$ & $\begin{array}{c}\text { Супровід студентів у створенні } \\
\text { цифрового контенту, розробці } \\
\text { практико-орієнтованих проєктів }\end{array}$ \\
\hline Студент & $\begin{array}{l}\text { Споживання } \\
\text { контенту та } \\
\text { відомостей }\end{array}$ & $\begin{array}{l}\text { Створення цифрового контенту, } \\
\text { практико-орієнтованих проєктів }\end{array}$ \\
\hline
\end{tabular}

По-п'яте, покращення цифрових компетенцій студентів можливе тільки у випадку ефективної міжсекторальній взаємодії стейкхолдерів (зацікавлених сторін) - державних органів, університетів, IT-компаній, громадських організацій. Співпраця між стейкхолдерами має сприяти обміну інформацією про попит та пропозицію цифрових навичок, їх засвоєнню на робочому місці і проходженню практики.

По-шосте, в Україні потрібна система моніторингу та збору статистичних даних щодо володіння цифровими компетентностями на всіх рівнях освіти. Створення такої системи дозволить зібрати 
необхідні дані для аналізу і прийняття рішень стосовно покращення ситуації.

По-сьоме, в Україні потрібно запровадити адресному політику 3 покращення цифрових компетенцій щодо певних груп населення, 3 не використовувати уніфікований підхід. Результатом цифрової трансформації має бути не тільки розвиток цифрових інфраструктури або навичок, а забезпечення появи соціальних «видимих» результатів онлайн-взаємодії у громадян (приріст економічного, культурного та інших форм капіталу) внаслідок використання вебресурсів, на вирішення проблем, що виникають в повсякденній діяльності.

Реалізація пропонованих рекомендацій дасть можливість системі вищої освіти ефективно працювати над формуванням цифрових компетенцій молоді і розбудовувати цифрову економіку та суспільство, а головне підготувати людські ресурси до повноправного функціонування на ринку праці.

1. Про освіту : Закон України від 05 вересня 2017 р. № 2145-VIII. URL: https://zakon.rada.gov.ua/laws/show/2145-19 (дата звернення: 10.03.2021). 2. Про вищу освіту: Закон України від 01 липня 2014 р. № 1556-VIII. URL: https://zakon.rada.gov.ua (дата звернення: 10.03.2021). 3. Волобоєва І. 0. Формування компетентнісної компоненти людських ресурсів (на прикладі банківських установ) : автореф. дис. ... канд. екон. наук : 08.00.07 / Київ. нац. екон. ун-т ім. Вадима Гетьмана. Київ, 2019. 22 с. 4. Макелвил В. Исследование компетенций. М. : Наука, 1982. 5. Демьянченко Н. В. Компетенция персонала как основа формирования конкурентных преимуществ организации в постиндустриальной концепции менеджмента. Вестник Белгородского университета потребительской кооперации «Кооперативное образование». 2016. № 4. C. 8-12. 6. Boyatzis Richard E. The competent manager: a model for effective performance / Richard E. Boyatzis. John Wiley \& Sons. 1982. 7. URL: https://ec.europa.eu/jrc/en/publication/eur-scientific-and-technical-researchreports/digcomp-20-digital-competence-framework-citizens-update-phase-1-

conceptual-reference-model (дата звернення: 10.03.2021). 8. Олешко А. А., Гороховець Є. В. Інформаційно-комунікаційні технології та людський розвиток. URL: http://www.investplan.com.ua/pdf/16_2019/4.pdf (дата звернення: 10.03.2021). 9. Van Deursen A. J. A. M., Helsper E., Eynon R., Van Dijk J. A. G. M. The Compoundness and Sequentiality of Digital Inequality. International Journal of Communication. 2017. No. 11. Pp. 452-473. 10. The Networked Readiness Index. URL: https://networkreadinessindex.org/wp-content/uploads/2020/11/NRI-2020-V8_2811-2020.pdf (дата звернення: 10.03.2021). 11. URL: http://surl.li/klyz (дата звернення: 10.03.2021). 12. URL: https:/osvita.diia.gov.ua/ (дата звернення: 10.03.2021). 13. URL: https://egap.in.ua/projects/doslidzhennia-tsyfrovoihramotnosti-ukraintsiv/ (дата звернення: 10.03.2021). 14. Van Deursen A. J. A. M., Van Dijk J.A. G. M. The Digital Divide Shifts to Differences in Usage. New Media and Society. 2013. No. 16. Pp. 507-526. 


\section{REFERENCES:}

1. Pro osvitu : Zakon Ukrainy vid 05 veresnia 2017 r. № 2145-VIII. URL: https://zakon.rada.gov.ua/laws/show/2145-19 (data zvernennia: 10.03.2021). 2. Pro vyshchu osvitu : Zakon Ukrainy vid 01 lypnia 2014 r. № 1556-VIII. URL: https://zakon.rada.gov.ua (data zvernennia: 10.03.2021). 3. Voloboieva I. 0. Formuvannia kompetentnisnoi komponenty liudskykh resursiv (na prykladi bankivskykh ustanov) : avtoref. dys. ... kand. ekon. nauk : 08.00.07 / Kyiv. nats. ekon. un-t im. Vadyma Hetmana. Kyiv, 2019. 22 s. 4. Makelvil V. Issledovanie kompetentsiy. M. : Nauka, 1982. 5. Demyanchenko N. V. Kompetentsiya personala kak osnova formirovaniya konkurentnyih preimuschestv organizatsii $v$ postindustrialnoy kontseptsii menedjmenta. Vestnik Belgorodskogo universiteta potrebitelskoy kooperatsii «Kooperativnoe obrazovanie». 2016. № 4. S. 8-12. 6. Boyatzis Richard E. The competent manager: a model for effective performance / Richard E. Boyatzis. John Wiley \& Sons. 1982. 7. URL: https://ec.europa.eu/jrc/en/publication/eur-scientific-and-technicalresearch-reports/digcomp-20-digital-competence-framework-citizens-update-phase1-conceptual-reference-model (data zvernennia: 10.03.2021). 8. Oleshko A. A., Horokhovets Ye. V. Informatsiino-komunikatsiini tekhnolohii ta liudskyi rozvytok. URL: http://www.investplan.com.ua/pdf/16_2019/4.pdf (data zvernennia: 10.03.2021). 9. Van Deursen A. J. A. M., Helsper E., Eynon R., Van Dijk J. A. G. M. The Compoundness and Sequentiality of Digital Inequality. International Journal of Communication. 2017. No. 11. Pp. 452-473. 10. The Networked Readiness Index. URL: https://networkreadinessindex.org/wp-content/uploads/2020/11/NRI-2020-V8_2811-2020.pdf (data zvernennia: 10.03.2021). 11. URL: http://surl.li/klyz (data zvernennia: 10.03.2021). 12. URL: https://osvita.diia.gov.ua/ (data zvernennia: 10.03.2021). 13. URL: https://egap.in.ua/projects/doslidzhennia-tsyfrovoihramotnosti-ukraintsiv/ (data zvernennia: 10.03.2021). 14. Van Deursen A. J. A. M., Van Dijk J. A. G. M. The Digital Divide Shifts to Differences in Usage. New Media and Society. 2013. No. 16. Pp. 507-526.

Beztelesna L. I. ${ }^{[1 ;}$ ORCID ID: 0000-0002-0262-9334], Doctor of Economics, Professor, Vasyliv V. B. [1; ORCID ID: 0000-0003-4152-3345], Candidate of Engineering (Ph.D.), Associate Professor

${ }^{1}$ National University of Water and Environmental Engineering, Rivne

\section{ORGANIZATIONAL AND PEDAGOGICAL MECHANISM OF FORMATION DIGITAL COMPETENCE BY UNIVERSITY STUDENTS}

The education system of Ukraine creates wide opportunities for a person, including the acquisition of general and professional competencies. One of the key is digital competence. Due to the rapid change in technology, the world economy is facing a shortage of people with digital skills. That is why most countries include digital skills training as part of the overall 
strategy for education and development of the national digital economy. The Ministry of Digital Transformation of Ukraine has created a portal "Diia" on which, with the help of the test "Tsyfrohram", citizens are given the opportunity to check digital literacy. The average assessment of digital literacy of students contrasts with the statistics of the use of information and communication technologies by young people. Studies have shown that significant use of computers, mobile devices and the Internet only contributes to digital skills at the operational level. Significant volume / time consumption of digital technologies cannot be considered as proof of digital competence. Young people are mostly consumers of other people's content, not the creator of new, self-created content. It is proposed to introduce testing of digital skills of first-year students and, depending on their level, to differentiate curricula and form individual learning trajectories. It is necessary to change the paradigm of acquiring digital skills: the transition from the traditional provision of content and information to accompany students in the creation of digital content, the development of practiceoriented projects. To achieve success, effective inter-sectoral interaction of stakeholders - government agencies, universities, IT companies, NGOs is needed. The introduction of a targeted policy to improve digital competences for certain groups of people will also contribute to success.

Keywords: digital competencies; testing; educational trajectory; certificate.

Безтелесная Л. И. ${ }^{[1 ;}$ ORCID ID: 0000-0002-0262-9334], д.э.н., профессор, Васылив В. Б. [1; ORCID ID: 0000-0003-4152-3345], к.Т.н., доцент

${ }^{1}$ Национальный университет водного хозяйства и природопользования, г. Ровно

$$
\begin{gathered}
\text { ОРГАНИЗАЦИОННО-ПЕДАГОГИЧЕСКИЙ МЕХАНИЗМ } \\
\text { ФОРМИРОВАНИЯ ЦИФРОВОЙ КОМПЕТЕНТНОСТИ СТУДЕНТОВ } \\
\text { УНИВЕРСИТЕТОВ }
\end{gathered}
$$

Система образования Украины создает для граждан широкие возможности, в том числе и для получения общих и профессиональных компетенций. Одной из ключевых является цифровая компетентность. Несмотря на быстрое изменение технологий, мировая экономика сталкивается с дефицитом людей с цифровыми навыками. Именно поэтому большинство стран включают обучение цифровым навыкам как часть общей стратегии образования и развития национальной цифровой экономики. Министерством цифровой трансформации Украины создан портал «Дія», на котором с помощью теста «Цифрограм», гражданам 
предоставлена возможность проверить цифровую грамотность. Средняя оценка цифровой грамотности студентов контрастирует с статистикой использования информационно-коммуникационных технологий молодежью. Исследования показали, что значительные объемы использования компьютеров, мобильных устройств и Интернета способствуют только цифровым навыкам на операционном уровне. Значительное по объему/времени потребление цифровых технологий нельзя рассматривать как доказательство цифровой компетентности. Молодежь является в основном потребителем чужого контента, а не творцом нового, самостоятельно созданного. Предложено ввести тестирование цифровых навыков студентов первого курса и в зависимости от их уровня дифференцировать учебные программы и формировать индивидуальные учебные траектории. Необходимо изменение парадигмы получения цифровых навыков: переход от традиционного предоставления контента и сведений к сопровождению студентов В создании цифрового контента, разработке практикоориентированных проектов. Для достижения успеха необходимо наладить эффективное секторальное взаимодействие стейкхолдеров государственных органов, университетов, ИТ-компаний, общественных организаций. Способствовать успеху будет также внедрение адресной политики по улучшению цифровых компетенций определенных групп населения.

Ключевые слова: цифровые компетенции; тестирование; образовательная траектория; сертификат.

Отримано: 15 березня 2021 p. Прорецензовано: 20 березня 2021 р. Прийнято до друку: 26 березня 2021 р. 